\title{
Effect of Unani Formulation in Cervicitis (Warme-unqur-rahm): A Single-blind Randomized Placebo-controlled Trial
}

\author{
Shabnam Zahid ${ }^{1 *}$, Hina Rehman ${ }^{2}$, Aysha Raza $^{1}$, Fahmida Kousar ${ }^{1}$ \\ 1Department of Ilmul Qabalat wa Niswan wa Atfal, Ayurvedic \& Unani Tibbia College, Karol Bagh, New Delhi. \\ 2 Research officer, Central research institute of Unani Medicine, Hyderabad, Telangana.
}

*Corresponding author: Shabnam Zahid, Research Scholar, Department of IlmulQabalatwaAmrazeNiswan (OBG), Ayurvedic and Unani Tibbia College, Karol Bagh, New Delhi, India, Tel: +919015622077; E-mail: shabnamparveen9@gmail.com

Received date: Febuary 16, 2016; Accepted date: March 22, 2016, 2016; Published date: March 28, 2016

Copyright: $@ 2016$ Zahid S, et al. This is an open-access article distributed under the terms of the Creative Commons Attribution License, which permits unrestricted use, distribution, and reproduction in any medium, provided the original author and source are credited.

\author{
Abstract \\ Objective: To evaluate the efficacy and safety of Polyherbal Unani formulations (PHUFs) with placebo in Warme- \\ unqur-rahm (Cervicitis).
}

Methods: A Randomized single-blind placebo controlled trial was designed to compare the efficacy of Unani formulations against placebo in diagnosed cases of cervicitis in the Department of Gynaecology of Ayurvedic \& Unani Tibbia College, Delhi. Sixty married female participants with age group of 18-40 years having symptoms of cervicitis with no systemic illness and sexually transmitted diseases and not using oral or intrauterine contraceptives were randomly allocated to receive either test drug $(n=30)$ or placebo $(n=30)$ for three months.

In the test group, sufoofe sailan (PHUF) $5 \mathrm{gm}$ orally was given twice daily and intravaginally humul (pessary) of isapghol (Isapgol: Plantago ovata Forsk) and alsi (Linseed: Linum usitatissimum L.) soaked in arqe gulab (rose water) was kept at mid-cycle for 10 days for three consecutive cycles and the placebo was given for same protocol. On the basis of improvement in subjective and objective parameters the response of treatment was graded as cured, improved and not cured. Results were analyzed by Chi-square/Fisher Exact test and Student t test.

Results: There was a significant improvement in the subjective and objective parameters in test group after treatment with $P<0.001$. Cervical discharge, cervical erythema and cervical oedema were significantly reduced $(P<$ $0.001)$ after three months of treatment. Interpretation and conclusion: Study revealed that test drug formulations were effective and safe in the management of cervicitis. Besides, the trial should be conducted on large sample size for effectiveness of drug.

Keywords: Warme-unqur-rahm; STDs; Cervicitis; Sufoofe sailan; Polyherbal Unani formulation

\section{Introduction}

Gynaecological infections are common worldwide. Diseases of the cervix are common in almost all sexually active women as cervix is the most common site of genital infection [1]. The incidence of cervicitis is high about $30-45 \%$ in some STI clinic populations and sexually transmissible pathogens are present in most of the cases [2-3]. Cervicitis (Warme-unqur-rahm) is a clinical syndrome characterised with mucupurulent cervical discharge and signs of inflammation of cervix such as oedema and easily induced cervical bleeding (friability) $[3,4]$.

Other subtle signs includes cervical ectopy with identification of $\geq 10$ PMNLs per high power field in gram stained smear of cervical secretions $[5,6]$. The presence of above finding suggest either Neisseria gonorrhoea or Chalamydial infection but studies revealed that above organism are identified in only half or less than half of cases of cervicitis and causes of rest cases remain unknown [7,8].

Mycoplasma genitalium, Mycoplasma hominis, Ureaplasma urealyticum, Bacterial vaginosis, Herpes simplex virus (HSV),
Trichomonas vaginalis etc. are organisms variably present in rest of cases and often called nonspecific cervicitis (NSC) $[2,4,9]$.

Chronic cervicitis is more common, seen in about $35-85 \%$ of women with higher prevalent among parous $[10,11]$. Sacral backache, lower abdominal pain and dyspareunia are other symptoms of cervicitis. Unfortunately, infection of the cervix is often asymptomatic and represents a reservoir for sexual and perinatal transmission of pathogenic micro-organisms.

Hence, timely and correct diagnosis is essential as improper diagnosis and incorrect management can lead to serious consequences like PID, cervical neoplasias, infertility and adverse outcomes of pregnancy and new born $[2,5]$. It is also associated with increased shedding of HIV-1 from the cervix in the absence of chlamydial and gonococcal infection [12].

Centers for Disease Control and Prevention (CDC) recommends Chlamydia Trachomatis screening at least annually for all women aged 25 years of age and younger, because the majorities of infections in women are asymptomatic and do not usually cause visible signs of cervicitis [13].

Cervicitis affects many aspects of quality of life including reproductive ability and sexual functioning. Mental health and the ability to work and perform routine physical activities are also affected. 
The initial therapy for cervicitis in conventional system is the use of antibiotics and antifungal drugs both orally and locally. Increase use of broad-spectrum antibiotic results in antibiotic resistance. Failure of medical treatment (after two or three attempts) further needs surgical interventions by diathermy, cauterization, cryotherapy, laser ablation, and others which cause further complications.

None of these treatments provides the definite efficacy in spite of high cost and side effects. Hence, there is a need for alternate therapy which is safe, effective, easily available and free from side effects.

Presently Complementary therapies are more accepted due to invidious effect of contemporary therapy. Research shows that almost half $(49 \%)$ of women of reproductive age reported to use Complementary therapies [14]. One of complementary medicine is Unani system of medicine or Greco-Arab medicine, which was originated by Hippocrates (460-377 BC) and flourished by Arabs (9-13 AD) and Mughal physicians. Unani System of Medicine is bestowed with a number of single herb or formulations that have been in used for cervicitis since antiquity. Each and every part of the herbs are being used for a number of pharmacological actions and a range of herbal preparations are made by these including sufoof (powders), joshanda (decoction), arq (extract) and many more.

For present study Polyherbal formulation (PHF), "Sufoof" was selected as PHF have synergistic, agonistic and antagonistic actions that work to produce a wide range of therapeutic activity with fewer side effects. Intravaginally humul of Isapgol and Linseed for warmeunqur-rahm has been documented by eminent Unani scholars.

Sufoofe sailan has been mentioned to treat leucorrhoea in various classical texts but it has been clearly mentioned that the most common cause of leucorrhoea is warme-unqu-rahm [15-17]. Various ingredients of above formulation shown to have antimicrobial, [18-21] anti-inflammatory, [22-24] antioxidant, [25-26] analgesic, [22,24,26] immunomodulator [27] and wound healing properties [28]. Considering the aforementioned fact, the present study was carried out to evaluate the efficacy PHUFs in the management of cervicitis.

\section{Material and Methods}

This was a single-centre, single-blind, placebo controlled and parallel group study with equal randomization (1:1). The study was conducted at Delhi, India.

\section{Participants}

Sixty married participants between ages of 18-40 years having vaginal discharge, low backache, lower abdominal pain, dysuria, foul smell, pruritus vulvae, dyspareunia and post coital bleeding attending Obstetrics and Gynaecology OPD of Ayurvedic and Unani Tibbia College Hospital, Delhi during March 2013 to February 2014 were included in the study. Approval of study was taken from the Departmental Review Board. The subjects were randomly assigned in the test group $(\mathrm{n}=30)$ and the control group $(\mathrm{n}=30)$ using a computer generated randomization table.

Duly signed informed consents were obtained from all the patients prior to the initiation of the study. Patients with pelvic pathology, systemic illness, unmarried and pregnant women were excluded. Women using contraceptive measures (IUCD, OCPs) and having history of conisation, cryotherapy and cauterization were also excluded. All participants were thoroughly evaluated prior to study. Subjects having symptoms of cervicitis were underwent pelvic examination (in dorsal position). First vulva and perineum were examined for any discharge, erythema, excoriation, and any other skin changes. Speculum examination was done to note the condition of vagina and cervix (Edema, erythema, congestion, discharge, erosion) and bimanual examination was done to note the cervical texture, external os, hypertrophy, motion tenderness and uterine position (AV/ RV). Simultaneously, Endocervical swab culture, Gram staining of endocervical secretion's smear and Pap smear were taken.

After a clinical diagnosis of cervicitis, all patients underwent certain investigations, including complete blood picture, erythrocyte sedimentation rates, random blood sugar, and complete urine analysis to exclude systemic illnesses. VDRL \& HIV I \& II to exclude STDs, pelvic ultrasound were done to exclude pelvic pathology and Pap smear to exclude malignancy.

\section{Intervention}

Ingredients of Sufoofe sailan include; Gul-e-Dhawa (Woodfordia fructicosa Kurz.), Gul-e-fufal (Areca catechu L.), Mochras (Salamalia malabarica Scholts \& Endl.) and Gond-e-molasri (Mimusops elangi L.). Locally humul (pessary) of Isapgol (Plantago ovata Forsk.) and Alsi (Linum usitatissimum L.) were used. All the drugs were purchased from drug retailer of Delhi and were identified by taxonomist working in CSIR-NISCAIR (National Institute of Science Communication and Information Research), Dr. K.S. Krishnan Marg, New Delhi 11012.

The ingredients of Sufoofe sailan were finely powdered and filled in dry plastic packets and stored at cool and dry place while for placebo group capsules of wheat flour were made and filled in similar packets. For humul preparation, both Isapgol and Linseed were finely powdered and soaked in arq-e-gulab and this preparation was evenly applied on the humul and kept intravaginally at night in the mid-cycle under aseptic precautions.

In test group 5 gm of sufoofe sailan twice daily was given orally for 3 months and intravginally humool of Isapgol and Linseed was kept for 10 days after menses for three consecutive cycles. In placebo group 2 capsules of roasted flour twice daily were given orally, while intravaginally only humul of arq-e-gulab was given for the same protocol. The study duration was divided into 3 visits of follow-up of one month each at mid cycles (after menses) during treatment.

At each follow up patients were enquired about the signs and symptoms of cervicitis particularly about vaginal discharge, low backache, lower abdominal pain, dysuria, foul smell, pruritus vulvae, dyspareunia and post coital bleeding.

Pelvic examination was done at baseline, every month (mid cycles) and after three months of treatment to note the changes of cervix. Progression and regression of symptoms were recorded in case record form. Endocervical swab culture and Gram staining of endocervical secretion's smear were taken before and after treatment. Compliance to therapy was assessed at every follow-up by examining the packets in which medication was dispensed at previous visit. Participants were informed not to take any other concomitant treatment during study.

\section{Outcomes measures}

Effectiveness of trial drugs were assessed by reduction in subjective and objectives parameters. Subjective parameter comprises symptoms of cervicitis (lowbackache, lower abdominal pain, discharge per vagina, dysuria, dyspareunia, post coital bleeding). Intensity of low backache and lower abdominal pain was assessed by Visual Analogue 
Scale (VAS). VAS is commonly used validated scale due to its simplicity and reliability, containing a $10 \mathrm{~cm}$ line $(0-10$ defined as no pain to worst pain) [29].

Discharge per vaginum was graded from 0 to 4 grade: Score: 1 -No discharge; 2-Mild (streak/spotting on undergarments); 3-Moderate (stain on undergarments); Score: 4-Severe (using pads) [12]. The other subjective parameters like dysuria, dyspareunia, and post coital bleeding were based on the arbitrary four point scale $(0=$ None, $1=$ Mild, 2 = Moderate, 3 = Severe) and foul smell and pruritus vulvae were assessed by the presence (score 1) and absence (score 0). Objective Parameters was assessed by female genital infection grading system given by DAIDS as an addendum in 2009 [30].

It includes cervical discharge, cervical erythema, cervical oedema and friability and cervical motion tenderness. On the basis of improvement in subjective and objective parameters before, during and after the treatment, the response was graded as follows: Cured; Complete resolution of signs and symptoms with $<10$ WBCs per high power field and absence of bacteria on cervical gram stain and culture report should be negative.

Improved; Incomplete resolution of signs and symptoms with $<10$ WBCs per high power field and absence of bacteria on cervical gram stain and negative culture report. Or Complete resolution of signs and symptoms with $=10 \mathrm{WBCs}$ per high power field with absence or presence of bacteria on cervical gram stain and negative culture report. Not cured; no apparent response or worsening of signs and symptoms and $>10$ WBCs per high power field and presence of bacteria on cervical gram stain and positive culture report.

\section{Adverse reactions or events}

The safety of the drug was assessed by Serum Glutamic Oxaloacetic Transaminase (SGOT), Serum Glutamic Pyruvic Transaminase (SGPT), alkaline phosphatase, blood urea, serum creatinine and haemoglobin \& ESR at baseline and after three months of treatment. All the participants were requested to report any adverse event during the trial.

\section{Statistical analysis}

The Statistical software namely SAS 9.2, SPSS 15.0, Stata 10.1, MedCalc 9.0.1, Systat 12.0 and $\mathrm{R}$ environment ver.2.11.1 were used for the analysis of the data. Student $t$ test (two tailed, independent) has been used to find the significance of study parameters on continuous scale between two groups (Inter group analysis) on metric parameters.

Mann Whitney $U$ test has been used to find the significance between two groups for parameters on non-interval scale and Student $t$ test (two tailed, dependent) has been used to find the significance of study parameters on continuous scale within each group. Chi-square/ Fisher Exact test has been used to find the significance of study parameters on categorical scale between two or more groups.

\section{Result}

\section{Participants flow}

A total of 131 participants of cervicitis were screened during the study period. Out of which 46 participants refused to participate; 25 were excluded and the rest of them (60) were randomized into experimental and placebo groups.
Two patients in the placebo group were drop out due to no improvement in symptoms of cervivcitis. The final analysis was conducted on 58 patients (Figure 1).

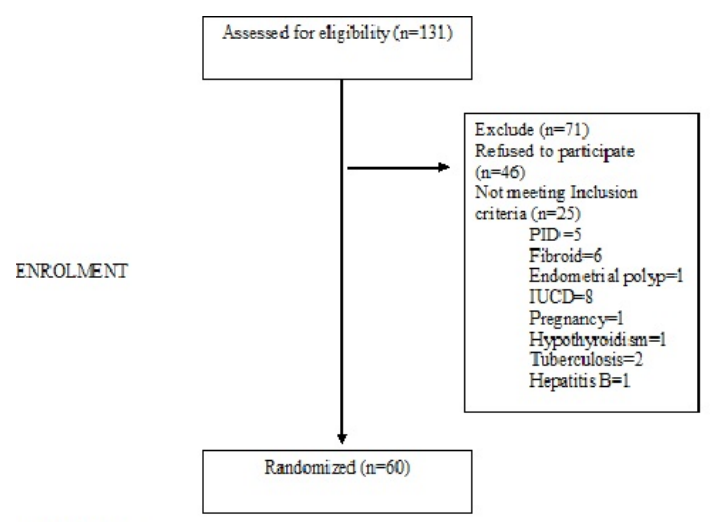

ALLOCATION
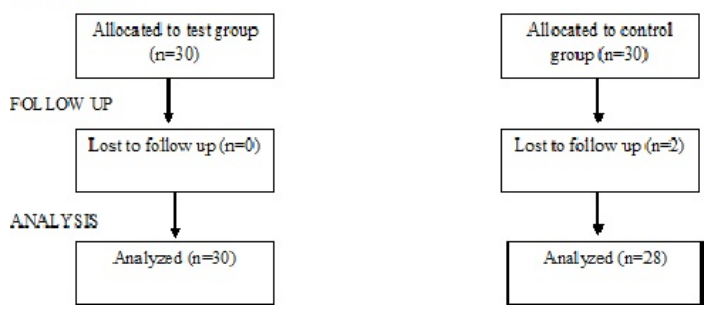

Figure 1: Flow diagram of participants.

\section{Baseline data}

No significant difference was identified between the test and placebo groups with regard to basic demographic data (including age, education, socioeconomic status, menstrual and obstetric history and contraceptive measures) with $\mathrm{P}>0.05$ (Table 1). Thus the participants were homogenous before intervention.

The present study conducted on 60 patients of cervicitis aged between 18-40 years showed the highest incidence (53.3\%) of cervicitis in the age group of 20-30 years. All patients have inflammatory changes in the Pap smear (18-mild, 38-moderate, 4-severe smear).

\begin{tabular}{|l|l|l|}
\hline Characteristic variables & $\begin{array}{l}\text { Test group } \\
(\mathrm{n}=30)\end{array}$ & $\begin{array}{l}\text { Control group } \\
(\mathrm{n}=30)\end{array}$ \\
\hline Age in years & $16(53.3 \%)$ & $19(63.3 \%)$ \\
\hline $20-30$ & $14(46.7 \%)$ & $11(36.7 \%)$ \\
\hline $31-40$ & $31.27 \pm 5.06$ & $29.97 \pm 5.48$ \\
\hline Mean \pm SD & $13(43.3 \%)$ & $14(46.7 \%)$ \\
\hline Socio economic status & $12(40 \%)$ & $8(26.7 \%)$ \\
\hline Upper lower & $5(16.7 \%)$ & $8(26.7 \%)$ \\
\hline Lowe middle & & \\
\hline Upper middle & & \\
\hline Education & & \\
\hline
\end{tabular}


Citation: Zahid S (2016) Effect of Unani Formulation in Cervicitis (Warme-unqur-rahm): A Single-blind Randomized Placebo-controlled Trial. Altern Integr Med 5: 213. doi:10.4172/2327-5162.1000213

Page 4 of 7

\begin{tabular}{|c|c|c|}
\hline Illiterate & $15(50 \%)$ & $14(46.7 \%)$ \\
\hline Primary & $4(13.3 \%)$ & $0(0 \%)$ \\
\hline Secondary & $3(10.0 \%)$ & $7(23.3 \%)$ \\
\hline High school & $6(20 \%)$ & $6(20 \%)$ \\
\hline Graduate or above & $0(0 \%)$ & $3(10.0 \%)$ \\
\hline \multicolumn{3}{|l|}{ Occupation } \\
\hline Employee & $2(6.7 \%)$ & $4(13.3 \%)$ \\
\hline Housewife & $28(93.3 \%)$ & $26(86.7 \%)$ \\
\hline \multicolumn{3}{|l|}{ Obstetric History } \\
\hline \multicolumn{3}{|l|}{ Parity } \\
\hline 0 & $3(10 \%)$ & $1(3.3 \%)$ \\
\hline 42401 & $10(33.3 \%)$ & $14(46.7 \%)$ \\
\hline 42493 & $17(56.7 \%)$ & $14(46.7 \%)$ \\
\hline$>5$ & $0(0 \%)$ & $1(3.3 \%)$ \\
\hline \multicolumn{3}{|l|}{ Abortion } \\
\hline 0 & $22(73.3 \%)$ & $22(73.3 \%)$ \\
\hline 42401 & $8(26.7 \%)$ & $8(26.7 \%)$ \\
\hline \multicolumn{3}{|l|}{ Menstrual History } \\
\hline Age at menarche(yrs) & $12.83 \pm 1.23$ & $12.82 \pm 1.11$ \\
\hline
\end{tabular}

\begin{tabular}{|l|l|l|}
\hline Duration of cycle (in days) & $27.83 \pm 2.39$ & $28.23 \pm 2.3$ \\
\hline Duration of flow (in days) & $4.23 \pm 1.57$ & $4.23 \pm 2.03$ \\
\hline Contraception & & \\
\hline Nil & $10(33.3 \%)$ & $12(40 \%)$ \\
\hline Condom & $16(53.3 \%)$ & $14(46.7 \%)$ \\
\hline Tubectomy & $4(13.3 \%)$ & $4(13.3 \%)$ \\
\hline Cytological pattern & & \\
\hline Mild & $9(30 \%)$ & $9(30 \%)$ \\
\hline Moderate & $19(63.3 \%)$ & $19(63.3 \%)$ \\
\hline Severe & $2(6.7 \%)$ & $2(6.7 \%)$ \\
\hline $\begin{array}{l}\text { Data are presented as Mean } \pm \text { SD and percentage. Analysis was done by } \\
\text { Student } t \text { test (two tailed, independent) and Mann Whitney U test. P > 0.05; non- } \\
\text { significant. }\end{array}$ & \\
\hline
\end{tabular}

Table 1: Comparison of basic variables of patients in test group and control group.

\section{Subjective parameters}

The mean \pm SD scores of both groups are shown in Table 2. In the test group, a significant difference was observed regarding the alleviation of vaginal discharge $(\mathrm{P}<0.001)$, low backache $(\mathrm{P}<0.001)$, lower abdominal pain $(\mathrm{P}<0.001)$, dyspareunia $(\mathrm{P}<0.001)$ after 3 months of intervention (Table 2).

\begin{tabular}{|c|c|c|c|c|c|c|}
\hline \multirow[t]{2}{*}{ Parameters } & \multicolumn{2}{|c|}{ Test group $(n=30)$} & \multirow[t]{2}{*}{$P$ value } & \multicolumn{2}{|c|}{ Control group $(n=30)$} & \multirow[t]{2}{*}{$P$ value } \\
\hline & Baseline & 3 months & & Baseline & 3 months & \\
\hline Vaginal discharge & $1.73 \pm 0.45$ & $0.30 \pm 0.47$ & $<0.001^{\star *}$ & $1.73 \pm 0.44$ & $1.71 \pm 0.46$ & 0.328 \\
\hline Low backache & $5.03 \pm 1.29$ & $1.03 \pm 1.06$ & $<0.001^{* *}$ & $5.07 \pm 1.28$ & $4.89 \pm 1.29$ & $0.050^{*}$ \\
\hline Lower Abdominal pain & $3.36 \pm 0.67$ & $0.03 \pm 0.18$ & $<0.001^{* *}$ & $3.20 \pm 0.41$ & $3.14 \pm 0.59$ & 0.326 \\
\hline Dysurea & $0.17 \pm 0.38$ & $0.00 \pm 0.00$ & $0.025^{*}$ & $0.10 \pm 0.31$ & $0.11 \pm 0.31$ & 1.000 \\
\hline Dyspareunia & $0.43 \pm 0.50$ & $0.00 \pm 0.00$ & $<0.001^{\star *}$ & $0.37 \pm 0.49$ & $0.39 \pm 0.49$ & 0.317 \\
\hline Post coital bleeding & $0.13 \pm 0.35$ & $0.00 \pm 0.00$ & $0.046^{*}$ & $0.00 \pm 0.00$ & $0.00 \pm 0.00$ & 1.000 \\
\hline Nil & $26(86.7 \%)$ & $30(100 \%)$ & & $30(100 \%)$ & $30(100.0 \%)$ & \\
\hline Yes & $4(13.3 \%)$ & $0(0 \%)$ & & $0(0 \%)$ & $0(0 \%)$ & \\
\hline \multicolumn{7}{|l|}{ Foul smell } \\
\hline No & $5(16.7 \%)$ & $30(100 \%)$ & & $10(33.3 \%)$ & $12(40 \%)$ & \\
\hline Yes & $25(83.3 \%)$ & $0(0 \%)$ & & $20(66.7 \%)$ & $16(53.3 \%)$ & \\
\hline \multicolumn{7}{|l|}{ Pruritus vulvae } \\
\hline No & $18(60 \%)$ & $30(100 \%)$ & & $22(73.3 \%)$ & $24(80.0 \%)$ & \\
\hline Yes & $12(40 \%)$ & $0(0 \%)$ & & $8(26.7 \%)$ & $6(20 \%)$ & \\
\hline
\end{tabular}


Data are presented as Mean $\pm S D$ and percentage. Analysis was done by Student $t$ test (two tailed, dependent). ${ }^{*}$ Moderately significant $(P$ value: $0.01<P \leq 0.05)$; ${ }^{*}$ Strongly significant $(\mathrm{P}$ value: $\mathrm{P} \leq 0.01)$

Table 2: Effect of test drug and placebo on subjective parameters.

\section{Objective parameters}

The Objective parameters (cervical discharge, cervical erythema, cervical oedema and friability and cervical motion tenderness) of the test group improved significantly after three months of treatment $(\mathrm{P}<$ $0.001)$. While non-significant difference was seen in placebo group. Gram negative bacteria were seen in smear of $24(80 \%)$ and $25(83.3 \%)$ patients in test group and control group respectively. 22 patients were improved and showed no bacteria in smear after treatment in test group. 7 patients in test and 5 in control group showed positive culture report. No causative pathogen was found in $23(76.7 \%)$ and $25(83.3 \%)$ in test and control group respectively (Table 3 ).

\begin{tabular}{|c|c|c|c|c|c|c|}
\hline \multirow[t]{2}{*}{ Parameters } & \multicolumn{2}{|c|}{ Test group $(n=30)$} & \multirow[t]{2}{*}{$P$ value } & \multicolumn{2}{|c|}{ Control group $(n=30)$} & \multirow[t]{2}{*}{$P$ value } \\
\hline & Baseline & 3 months & & Baseline & 3 months & \\
\hline Endocervical discharge & $1.70 \pm 0.47$ & $0.37 \pm 0.49$ & $<0.001^{* *}$ & $1.67 \pm 0.48$ & $1.68 \pm 0.48$ & 1.000 \\
\hline Cervical erythema & $1.27 \pm 0.45$ & $0.17 \pm 0.38$ & $<0.001^{* *}$ & $1.07 \pm 0.25$ & $1.07 \pm 0.26$ & 1.000 \\
\hline Cervical edema \& friability & $1.07 \pm 0.25$ & $0.07 \pm 0.25$ & $<0.001^{* *}$ & $1.17 \pm 0.38$ & $1.04 \pm 0.19$ & $0.043^{*}$ \\
\hline Cervical motion tenderness & $1.00 \pm 0.45$ & $0.03 \pm 0.18$ & $<0.001^{* *}$ & $1.03 \pm 0.18$ & $1.00 \pm 0.00$ & 0.326 \\
\hline WBCs & $26.07 \pm 9.35$ & $4.57 \pm 4.79$ & $<0.001^{* *}$ & $25.77 \pm 8.29$ & $28.39 \pm 10.18$ & $0.056+$ \\
\hline \multicolumn{7}{|l|}{ Bacteria } \\
\hline Yes & $24(80 \%)$ & $2(6.7 \%)$ & & $25(83.3 \%)$ & $26(86.7 \%)$ & \\
\hline No & $6(20 \%)$ & $28(93.3 \%)$ & & $5(16.7 \%)$ & $4(13.3 \%)$ & \\
\hline \multicolumn{7}{|l|}{ Cervical swab (C\&S) } \\
\hline Escherichia coli & $3(10 \%)$ & $1(3.3 \%)$ & & $1(3.3 \%)$ & $1(3.3 \%)$ & \\
\hline Klebseilla & $1(3.3 \%)$ & $0(0 \%)$ & & $1(3.3 \%)$ & $0(0 \%)$ & \\
\hline Stapylococcus & $3(10 \%)$ & $1(3.3 \%)$ & & $3(10 \%)$ & $3(10 \%)$ & \\
\hline Sterile & $23(76.67 \%)$ & - & & $25(83.4 \%)$ & - & \\
\hline
\end{tabular}

Table 3: Effect of test drug and placebo on objective parameters.

\section{Harms}

All investigations were within normal range in test group after three months of intervention and no obnoxious effect were observed.

\section{Outcome}

In the test group, out of 30 patients of cervicitis, $12(40 \%)$ were cured completely and $18(60 \%)$ were improved; while in control group no patients were cured completely but $4(13.3 \%)$ were improved. Comparison was done and it revealed that difference in cured and improved was strongly significant $(\mathrm{P}<0.001)$ (Table 4$)$.

\begin{tabular}{|l|l|l|l|}
\hline & Cured & Improved & Not cured \\
\hline $\begin{array}{l}\text { Test group } \\
(\mathrm{n}=30)\end{array}$ & $12(40 \%)$ & $18(60 \%)$ & Nil $(0 \%)$ \\
\hline Control group & Nil $(0 \%)$ & $4(13.3 \%)$ & $24(80 \%)$ \\
\hline
\end{tabular}

$(n=30)$

Data presented as percentage; test used Chi square Fisher exact; $\mathrm{P}<0.001$ considered strongly significant.

Table 4: Therapeutic response of test formulations and placebo on cervicitis.

\section{Discussion}

Cervicitis is probably the most frequent problem faced by gynaecologist, which is more complex because the inflammatory reaction in the cervix accompanies lesions of the corpus or the vagina. Cervicitis is commonly caused by STDs. It is a frequently asymptomatic inflammatory condition of the cervix [11,31-33]. Infective causes of acute and chronic cervicitis are more common than non-infective causes and include a wide spectrum ranging from 
bacterial, viral, protozoan and fungi micro-organisms commonly encountered in STIs [34].

According to Unani concept, there is defence power in the body known as tabiat-e-mudabbir-e-badan which keeps body immune from certain microbial diseases. It guides the body to produces certain specific substances which constitute humors and thus maintain normal temperament of humors (blood, phlegm, bile and black bile). Any derangement in these humours either qualitatively or quantitatively leads to disease [35]. As Unani Scholars claimed that warme unqur rahm is caused by Ufunat and dominance of Khilt dam or Safra (blood or bile humour) [36-37] which belongs to Warme har disease. Hence, it should be treated with barid (cold) wa yabis (dry) drugs and requires the drug having dafe ta'fun (antimicrobial) and mohallil (resolvant) properties to relieve infections and associated symptoms of cervicitis [17]. The temperament of Gule dhawa, Supari, Mochras and Molsari is barid wa yabis (which are the ingredients of safofe sailan) and assumed that these drugs reduce the inflammation or dominance of khilt. Furthermore; improvement may also be due to various activities of the ingredients of PHUF. These herbs possess mohallil-e-warm (antiinflammatory), dafe ta'fun (antimicrobial), mulattif (demulcent), mujaffif (desicant), munzij (concoctive) and qabiz (astringent) properties [38]. These herbs might have inhibited the proliferation and growth of microorganism and resolved the inflammatory process that led to the overall improvement in cervicitis. Recent studies also confirmed that these herbs possess antimicrobial, [18-21] antiinflammatory, [22-24] antioxidant, [25-26] analgesic, [22,24,26] immunomodulator [27] and wound healing properties [28]. Study reveals Isapgol to have antimicrobial activity against Staphylococcus aureus [20] and Escherichia coli [39] while Linseeds have wide range of activity against Staphylococcus aureus, Bacillus cereus, Klebsiella pneumonia [21]. Tabasum et al. have conducted clinical trial on Marham dakhlion in chronic cervicitis and cervical erosion and the study revealed significant results in relieving the symptoms. Marham dakhlion is an ointment and Plantago ovate and Linum usitatissimum are one of the constituents of the formulation [40]. Similar results of these herbs were seen in our study.

This study demonstrates that the Unani formulations were effective in the improving symptoms of cervicitis. Sufoofe sailan, orally and intravaginally humool of Isapgol and Linseed was found to be beneficial in reducing the signs and symptoms of cervicitis. No obnoxious adverse effects were observed and the formulation was found safe and well accepted by the subjects. It can be concluded that Unani formulations were found to be effective and can serves an alternative therapy in cervicitis. Although the study showed remarkable response, its limitations include small population and lack of long term follow up. Therefore, studies with large sample size with long follow-up period need to be carried out for further exploration of efficacy and safety of Unani formulation.

\section{Acknowledgements}

The authors are grateful to the head of institute Dr. K. K. Sijoria, for providing the facilities to carry out research. The authors are also grateful to Dr. K. P. Suresh, Scientist (Biostatistics), National Institute of Animal Nutrition and Physiology, Bangalore, for performing the statistical analysis.

\section{References}

1. Durr-e-Nayab (2005) Reproductive tract infection among women in Pakistan. Pakistan Development Review 44: 2131-158.

2. Lusk MJ, Konecny P (2008) Cervicitis: a review. Current Opinion in Infectious Diseases 21: 49-55.

3. Marazo JM, Martin DH (2007) Management of Women with Cervicitis. Clinical Infectious Diseases 44: S102-S110.

4. Schwebke JR, Weiss HL (2002) Interrelationships of Bacterial Vaginosis and Cervical Inflammation. Sexually transmitted disease pp: 59-64.

5. Sweet RL (1998) The Enigmatic cervix. Dermatol Clin. 16: 739-745.

6. Myziuk L, Romanowski B, Brown M (2001) Endocervical gram stains smears \& their usefulness in the diagnosis of chlamydia trachomatis. Sex Transm Infect 77: 103-106.

7. Paavonen J, Critchlow CW, De Reven I (1986) Etiology of cervical inflammation. American Journal of Obstetrics \& Gynecology 154: 556-564.

8. Taylor SN, Lensing S, Schwebke J, Lillis R, Mena LA, et al (2013) Prevalence and Treatment Outcome of Cervicitis of Unknown Etiology. Sex Transm Dis 40: 379-385.

9. Gaydos C, Maldies NE, Hardick A, Hardick J, Quinn TC (2009) Mcycoplasma genitalium as a contributor to the multiple etiologies of cervicitis in women attending sexually transmitted diseases Clinics. Sex Transm Dis 36: 598-606.

10. Kumar P, Malhotra N (2008) Jeffcoate's Principles of Gynaecology (7th edn.). New Delhi, Jaypee Brother Medical Publishers (P) Ltd pp: 30-34, 54-55, 347-349.

11. Padubidri VG, Daftary SN (2011) Shaw's Textbook of Gynaecology (15th edn.). Reed Elsevier India (P) Ltd pp: 6-9, 128, 324.

12. Workowsi KA, Berman S (2010) Sexually Transmitted Diseases Treatment Guidelines. MMWR; 59(RR-12) pp: 1-110.

13. CDC (2012) Update to CDC's sexually transmitted diseases treatment guidelines, 2010: oral cephalosporins no longer recommended treatment for gonococcal infections. MMWR 61: 590-594.

14. Eisenberg DA, Davis RB, Ettner SL, Appel S, Wilky S, et al. (1998) Trends in alternative medicine use in the United States, 1990-1997: results of a follow up national survey. JAMA 280: 1569-1575.

15. Kabeeruddin M (YNM) Bayaz-e-Kabeer. Vol. II. Hikmat Book Dipo, Hyderabad Dakkin p: 72

16. Anonymous (2006) National Formulary of Unani Medicine. Part I. New Delhi, Central Council of Research in Unani Medicine p: 242.

17. Kabeeruddin M (2003) Al-Akseer. Aejaz Publishing House, New Delhi pp: $1327-1332$

18. Parekh J, Chanda S (2007) In vitro antibacterial activity of the crude methanol extract of woodfordia fruticosa Kurz. Flower (Lythracea). Braz J Microbiol 38: 204-207.

19. Hada LS, Kakiuchi M, Hattori M, Namba T (1989) Identification of antibacterial principles against streptococcus mutans \& inhibitory principles against glucosyltransferase from the seed of areca catechu L. Phytotherapy Research 3: 140-144.

20. Motamedi H, Darabpour E, Gholipour M, Seyyed Nejad SM (2010) Antibacterial effect of ethanolic \& methanolic extracts of plantago ovate \& oliveria decumbens Endemic in Iran against some pathogenic bacteria. International Journal of Pharmacology 6: 117-122.

21. Firas A, Al-Bayati (2007) Antibacterial activity of Linum Usitatissiumum L. seeds \& active compound detection. Raj Journal Sci 18: 27-36.

22. Baravalia S, Vaghasiya YK, Chanda S (2012) Brine Shrimp Cytotoxicity, Antiinflammatory \& Analgesic properties of woodfordia fruticosa Kurz flowers. Iran J Pharm Res 11: 851-861.

23. Fernandez-Banares F, Hinojosa J, Sanchez-Lombrana JL, Navarro E, Martínez-Salmerón JF, et al. (1999) Randomized clinical trial of plantago ovata seeds (dietary fiber) as compared with mesalamine in maintaining remission in ulcerative colitis. Am J Gastroenterol 94: 427-433.

24. Kaithwas G, Mukherjee A, Chaurasia AK, Majumdar DK (2011) Antiinflammatory analgesic \& antipyretic activities of linum 
Citation: Zahid S (2016) Effect of Unani Formulation in Cervicitis (Warme-unqur-rahm): A Single-blind Randomized Placebo-controlled Trial. Altern Integr Med 5: 213. doi:10.4172/2327-5162.1000213

Page 7 of 7

usitatissimum L. (flaxseed/ linseed) fixed oil. Indian Journal of Experimental Biology 49: 932-938.

25. Lin ES, Li CC (2010) Evaluation of superoxide radical scavenging capacity \& reducing power of areca flower extracts. Journal of Medicinal Plants Research 4: 975-981.

26. Dar A, Faizi S, Naqvi S, Roome T, Zikr-ur-Rehman S, et al. (2005) Analgesic \& antioxidant activity of Mangiferin \& its derivatives: the structure activity relationship. Biol Pharm Bull 28: 596-600.

27. Shah AS, Juvekar AR (2010) In vitro \& in vivo immuno stimulatory activity of woodfordia fruticosa flowers on non specfic immunity. Pharma Biol 48: 1053-1058.

28. Gupta N, Jain VK (2011) Investigation of wound healing activity of methanolic extract of stem bark of mimusups elengi Linn. Afr J Tradit Complement Altern Med 8: 98-103.

29. Bijur PE, Silver W, Gallagher EJ (2001) Reliability of the Visual Analog Scale for Measurement of Acute Pain. Acad Emerg Med. 8: 1153-1157.

30. Anonymous (2004) Female Genital Grading Table for Use in Microbicide Studies. Addendum 1. Division of Aids Table For Grading The Severity of Adult And Pediatric Adverse Events. Version 1.0. November 2007 pp: 1-15.

31. Holmes KK, Stamm WE (1999) Lower genital tract infections in women. Sexually Transmitted Diseases (3rd edn.). New York, MC Graw-Hill pp: 761-781.
32. Falk L, Fredlend H, Jensen JS (2005) Signs \& symptoms of urethritis \& cervicitis among women with or without mycoplasma genitalium or chamydia tranchomatis infection. Sex Transm Infect 81: 73-78.

33. Donovan B (2004) Sexually transmissible infections other than HIV. Lancet 363: 545-556.

34. Nwachokor FN, Forae GD (2013) Morphological spectrum of nonneoplastic lesions of the uterine cervix in Warri, South-South, Nigeria. Nigerian Journal of Clinical Practice 16: 429-432.

35. Ahmed SI (1980) Introduction to Al-Umur Al-Tabi'yah. Saini Printers, Delhi pp: 15, 16, 40-42, 50-51, 76, 77.

36. Baghdadi IH (2007) Kitab Al-Makhtarat Fit-Tibb. (Urdu Translation). Vol. IV. New Delhi, CCRUM pp: 42-44.

37. Ibn Sina (2007) Al Qanoon. Vol. II Translated by Ghulam Husnain Kantoori. Delhi, Idara Kitabul Shifa p: 336, 337, 359.

38. Ghani N (YNM) Khazainul Advia. Part I-VI. Idara Kitab-us-Shifa pp: 229-230, 258-260, 700-701, 785-787, 1268, 1273-1274.

39. Ahmad N, Amir MK, Ayaz S, Ahmad S, Jan A, et al. (2012) Antimicrobial profile of the selected medicinal plants. International Journal of Chemical \& Life Sciences 1: 1039-1041.

40. Latafat T, Siddiqui MMH, Jafri SAH (1992) A clinical study of Marham Dakhlion on Chronic cervictis and cervical erosion. Anc Sci Life 11: 158-162. 